\title{
PPARs Link Early Life Nutritional Insults to Later Programmed Hypertension and Metabolic Syndrome
}

\author{
You-Lin Tain ${ }^{1,2, *}$, Chien-Ning Hsu ${ }^{3,4}$ and Julie Y. H. Chan ${ }^{2}$ \\ Received: 1 December 2015; Accepted: 21 December 2015; Published: 24 December 2015 \\ Academic Editor: Béatrice Desvergne \\ 1 Departments of Pediatrics, Kaohsiung Chang Gung Memorial Hospital, \\ Chang Gung University College of Medicine, Kaohsiung 833, Taiwan \\ 2 Institute for Translational Research in Biomedicine, Kaohsiung Chang Gung Memorial Hospital, \\ Chang Gung University College of Medicine, Kaohsiung 833, Taiwan; jchan@cgmh.org.tw \\ 3 Department of Pharmacy, Kaohsiung Chang Gung Memorial Hospital, Kaohsiung 833, Taiwan; \\ cnhsu@cgmh.org.tw \\ 4 School of Pharmacy, Kaohsiung Medical University, Kaohsiung 807, Taiwan \\ * Correspondences: tainyl@cgmh.org.tw; Tel.: +886-975-056-995; Fax: +886-7733-8009
}

\begin{abstract}
Hypertension is an important component of metabolic syndrome. Adulthood hypertension and metabolic syndrome can be programmed in response to nutritional insults in early life. Peroxisome proliferator-activated receptors (PPARs) serve as a nutrient-sensing signaling linking nutritional programming to hypertension and metabolic syndrome. All three members of PPARs, $\operatorname{PPAR} \alpha, \operatorname{PPAR} \beta / \delta$, and PPAR $\gamma$, are expressed in the kidney and involved in blood pressure control. This review provides an overview of potential clinical applications of targeting on the PPARs in the kidney to prevent programmed hypertension and metabolic syndrome, with an emphasis on the following areas: mechanistic insights to interpret programmed hypertension; the link between the PPARs, nutritional insults, and programmed hypertension and metabolic syndrome; the impact of PPAR signaling pathway in a maternal high-fructose model; and current experimental studies on early intervention by PPAR modulators to prevent programmed hypertension and metabolic syndrome. Animal studies employing a reprogramming strategy via targeting PPARs to prevent hypertension have demonstrated interesting results. It is critical that the observed effects on developmental reprogramming in animal models are replicated in human studies, to halt the globally-growing epidemic of metabolic syndrome-related diseases.
\end{abstract}

Keywords: developmental programming; hypertension; kidney; metabolic syndrome; nutrient sensing; peroxisome proliferator-activated receptor

\section{Introduction}

Metabolic syndrome and its comorbidities may prove to be the greatest crisis to global healthcare. Metabolic syndrome is a cluster of metabolic and cardiovascular symptoms, including insulin resistance, obesity, dyslipidemia, and hypertension. Among these, hypertension is an important component of this syndrome. The origins of susceptibility for many non-communicable diseases in adult, including metabolic syndrome and hypertension, can be traced back to the early life, referred to as "developmental programming" [1]. Early-life nutrition plays an essential role in placental and fetal growth, organogenesis, and development. Given that different nutritional insults can produce the same detrimental consequences that occur in adult life [2,3], a common mechanism might underlie the early-life developmental programming of metabolic syndrome in adulthood [4].

Glucose and related sugars, lipids, and amino acids are important cellular nutrients. The ability to sense and respond to the above environmental nutrient levels is essential for life, which is controlled 
by nutrient-sensing mechanisms and pathways [5]. Of note is that nutrient sensing nuclear receptors are key integrators of metabolic responses. Peroxisome proliferator-activated receptors (PPARs) are ligand-activated transcription factors of nuclear receptor superfamily involved in the control of nutrition and energy metabolism. To date, three isoforms of PPARs have been identified, namely $\operatorname{PPAR} \alpha, \operatorname{PPAR} \beta / \delta$, and PPAR $\gamma$. Importantly, PPARs have been increasingly recognized as key players in the pathogenesis of metabolic syndrome [6]. Although emerging evidence support PPARs may serve as therapeutic targets for treating the metabolic syndrome and its related diseases $[7,8]$, there remains a lack of definitive data on how and when to prevent the developmental programming of hypertension and metabolic syndrome via targeting on PPARs in early life.

Given that the PPARs serve as a nutrient-sensing signaling linking nutritional programming to metabolic syndrome, that the kidney plays a crucial role on the development of the cluster of metabolic diseases [3,9,10], and that PPARs have been implicated in many kidney diseases [8], this review aims to describe the interplay between RRARs, early life nutritional insults, and developmental programming, leading to hypertension and metabolic syndrome in later life, with an emphasis on the kidney.

\section{The Impact of Renal Programming in Programmed Hypertension and Metabolic Syndrome}

A number of mechanisms have been proposed to interpret the programmed hypertension and metabolic syndrome, including thrifty phenotype, catch up growth, glucocorticoid effects, epigenetic changes, and oxidative stress $[3,10,11]$. However, each of the proposed mechanisms examined in different models of developmental programming was unable fully define a common mechanism, which can drive programmed disease processes. Recently we have shown that programmed hypertension developed in the male offspring of rats exposed to a variety of nutritional insults in early life, including caloric restriction [12], maternal diabetes [13], high-fructose intake [14], postnatal high-salt intake [15], and postnatal high-fat diet [16]. Although several organs control blood pressure (BP), the developing kidney is particularly susceptible to the insults of programming. Data from the human patients and experimental models demonstrated some particular mechanisms in the kidney related to programmed hypertension, including reduced nephron numbers, oxidative stress, epigenetic regulation, activation of the renin-angiotensin system (RAS), and sodium transporters [1,2,9-20]. Importantly, renal programming has been identified as a driving mechanism of programmed hypertension $[2,10,11]$.

We recently analyzed the differential expressed genes (DEGs) induced by four different maternal insults in the offspring kidney using next-generation RNA sequencing (NGS) technology [2]. Our NGS data indicate that a diverse range of maternal nutritional insults might generate differentially programmed processes despite the same phenotype-programmed hypertension. Importantly, the PPAR signaling pathway was identified as a significantly regulated Kyoto Encyclopedia of Genes and Genomes (KEGG) pathway and shared by the caloric restriction, maternal diabetes, and high-fructose models [2].

PPARs are nuclear transcription factor and nutrient-sensing signaling that regulate metabolic and tissue developmental processes. Studies focusing on the mechanisms of such metabolic programming have implicated PPARs as a candidate gatekeeper pathway of developmental programming [21-23], although their relationship with programmed hypertension and metabolic syndrome remains to be established.

\section{Peroxisome Proliferator-Activated Receptors (PPARs) and the Kidney in Hypertension and Metabolic Syndrome}

The three PPAR isoforms have many aspects of shared biology but different tissue distributions and distinct biological effects [6-8]. The three PPARs, by acting as lipid sensors, are involved in regulating fatty acid oxidation, insulin sensitivity, and anti-inflammation. PPAR $\alpha$ is expressed mainly in the liver, heart, and kidney. PPAR $\alpha$ is predominantly involved in fatty acid utilization, ketogenesis, lipoprotein synthesis, and amino acid catabolism. PPAR $\beta / \delta$ is universally expressed in multiple tissues, especially expressed at high levels in skeletal muscle. Whereas PPAR $\beta / \delta$ function is to regulate 
adipose tissue metabolism, glucose metabolism, and muscle physiology. PPAR $\gamma$ is highly expressed in adipose tissue and acts as a master regulator of adipogenesis. PPAR $\gamma$ has been implicated in almost all features of metabolic syndrome, including obesity, hypertension, dyslipidemia, insulin resistance, and inflammation. The kidney expresses all three types of PPARs [8].

PPAR $\alpha$ ligands have been reported to lower BP in experimental models of hypertension [24,25]. PPAR $\beta / \delta$ activation also elicited antihypertensive effects [26]. However, PPAR $\gamma$ is hypertensive or hypotensive remains inconclusive [8,27]. Abundant clinical evidence suggest that administering PPAR $\gamma$ agonists, particularly thiazolidinedione (TZD) and a subgroup of angiotensin type 1-receptor blockers (ARBs), may be beneficial for patients with hypertension [25,27]. Nevertheless, the BP-lowering effects may be off-target or PPAR $\gamma$ independent [27]. Genetic studies showed the global PPAR $\gamma$ knockout model displays a hypotensive phenotype [28], which is consistent with a report showing that PPAR $\gamma$ stimulates renin gene expression [29]. Since the RAS cascade starts with the release of renin from the kidney, these observations point to a hypertensive role for PPAR $\gamma$ in BP control.

The roles of PPARs in metabolic syndrome has been reviewed and is covered elsewhere [6-8]. As the PPARs are involved fundamentally in regulating nutrition and energy homeostasis, they have been considered attractive drug targets for treating metabolic syndrome $[7,8]$. Among them, PPAR $\gamma$ is the leading therapeutic target and several PPAR $\gamma$-targeting drugs, such as TZD, has been developed and used clinically [30]. However, little attention has been paid to elucidate whether early target on PPARs can prevent the later development of programmed metabolic syndrome and hypertension.

\section{PPARs Link Maternal Nutritional Insults to Programmed Hypertension and Metabolic Syndrome}

PPAR forms a heterodimer with retinoid $X$ receptor (RXR), which binds to the peroxisome proliferation response element (PPRE), in the promoter region of PPAR target genes. The actions of PPAR are mainly in a ligand-dependent manner. In the absence of ligand, the PPAR/RXR heterodimer recruits co-repressors that maintain PPAR target genes in an inactive state. The addition of ligand causes dissociation of the co-repressors followed by the recruitment of co-activators, such as PPAR $\gamma$ coactivator- $1 \alpha$ (PGC-1 $\alpha$ ) and histone acetyltransferase (HAT), thus inducing the expression of PPAR target genes. Diverse endogenous and synthetic ligands for PPARs have been identified [31], including a variety of nutrients or their metabolites.

Nutrient-sensing signaling pathways reconcile fetal metabolism and development in response to maternal nutritional insults. Accordingly, a number of these signaling pathways exist in the kidney include PPARs, PGC- $1 \alpha$, silent information regulator transcript (SIRT), cyclic adenosine monophosphate-activated protein kinase (AMPK), and mammalian target of rapamycin (mTOR) pathway. SIRT1 and AMPK can mediate deacetylation and phosphorylation of PGC-1 $\alpha$ respectively [32], to regulate the expression of PPAR target genes. Next, mTOR has been reported to mediate PPAR activation [33]. Thus, the interplay of PPARs with other nutrient sensing signals allows the kidney to alter the gene expression, morphology, and function in response to maternal nutritional insults and thereby go through a process namely renal programming.

So far, there is a number of genes with PPREs or showing primary response to PPARs and their ligands, the so-called PPAR target genes [34,35]. Four lines of evidence suggest that maternal nutritional insults could mediate nutrient sensing mechanisms to regulate PPAR target genes, contributing to programmed hypertension. First, reduced nephron numbers play a role in programmed hypertension $[10,11]$. Several genes involved in kidney development are PPAR target genes, such as Pax2 [34], Eya1 [34], and Fgf2 [36]. Our previous NGS data demonstrated that $F g f 2$ was significantly modified above the chosen threshold in the kidneys of offspring at two weeks of age in response to maternal caloric restriction as well as diabetes [2]. Second, are emerging evidence supports that oxidative stress due to nitric oxide (NO)-reactive oxygen species (ROS) imbalance is important for programmed hypertension $[37,38]$. A previous report showed that PPAR $\gamma$ can directly regulate a 
vast array of genes to mediate oxidative stress, including Nos2, Nos3, Sod2, and Nrf2 [39]. Third, are observations that several PPAR target genes are epigenetic regulators, such as histone deacetylase 5 (Hdac5) and Sirt7 [34,40]. Fourth, are studies showing that several PPAR target genes are belonging to the RAS components or sodium transporters. PPAR $\gamma$ has been reported to stimulate renin gene expression [29]. Next, PPAR $\gamma$ can stimulate serine glucocorticoid kinase-1 (SGK1 encoding $S g k 1$ gene) and sodium hydrogen exchanger-3 (NHE3 encoding Slc9a3 gene) [41]. Taking into considerations that SGK1 can up-regulate several sodium transporters [42] and that increased sodium transporter expression is associated with programmed hypertension $[10,11]$, the alterations in sodium transporters in programmed hypertension is possible a PPAR signaling related mechanism. Therefore, maternal nutritional insults could affect nutrient sensing pathways, especially via PPAR target genes, to induce renal programming leading to programmed hypertension. These heuristic concepts are illustrated in Figure 1.

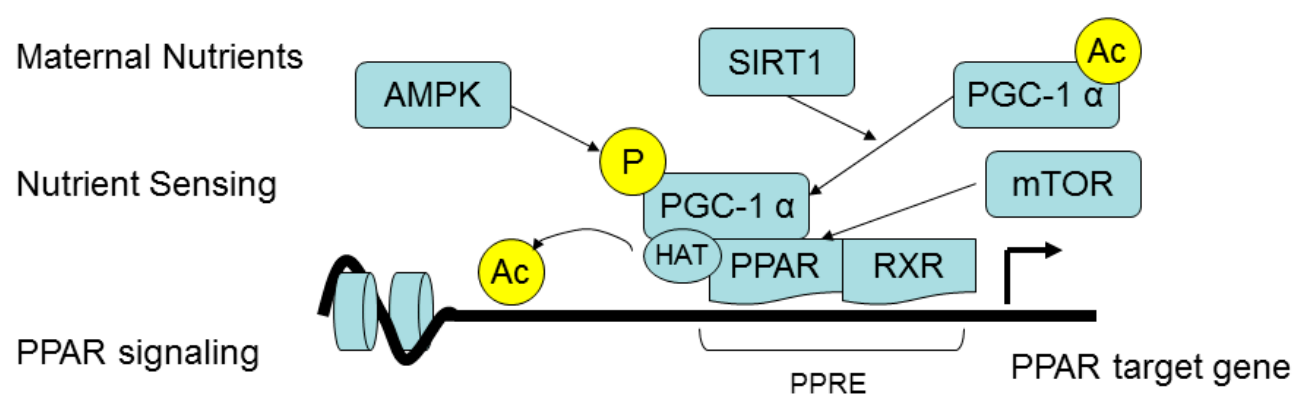

\begin{tabular}{|l|l|l|}
\cline { 2 - 3 } & Mechanisms & PPAR target gene \\
\cline { 2 - 3 } Renal Programming & Reduced nephron numbers & Pax2, Eya1, Fgf2 \\
\cline { 2 - 3 } & Oxidative stress & Nos2, Nos3, Sod2, Nrf2 \\
\cline { 2 - 3 } & Epigenetic regulation & Ren Sirt7 \\
\hline Activation of RAS & Sgk1, Slc9a3 \\
\hline Sodium transporters \\
\hline
\end{tabular}

Programmed Hypertension

Figure 1. A schema showing the link between maternal nutritional insults and programmed hypertension via PPAR signaling pathway. P, phosphorylation; Ac, acetylation.

\section{PPAR Signaling Pathway in Response to Maternal High-Fructose Intake}

Over the past few decades, a rise in metabolic syndrome has been linked to an increase in fructose consumption [43]. Thus, fructose-fed rat, which displays numerous features of the metabolic syndrome, has been generally used as an animal model to study metabolic syndrome and related diseases. Using a maternal high-fructose rat model, we recently found that maternal high-fructose intake induced several phenotypes of metabolic syndrome in adult offspring, including hypertension [14,44]. We used DAVID v6.7 (NIH, Bethesda, MD, USA) to gain biological insight from our NGS dataset [45]. We observed that PPAR signaling pathway is a significant KEGG pathway shared by one-day, three-week, and three-month-old offspring kidney exposed to maternal high-fructose intake [44]. Another significant KEGG pathway shared by three different developmental stages is arachidonic acid metabolism. In this regard, another of our study showing that the protein level and activity of soluble epoxide hydrolase (sEH encoding Ephx2 gene) are induced by maternal high-fructose exposure in offspring at three months of age [14]. Given that arachidonic acids are ligands for PPARs [7], 
that the Ephx2 is a PPAR target gene [35], and that increased expression/activity of sEH have been associated with hypertension [46], these observations implicate a role of PPAR signaling pathway for high-fructose-induced programmed hypertension.

In addition to the kidney, we analyzed DEGs induced by maternal high-fructose intake in the brain stem, liver, skeletal muscle, heart, and urinary bladder in male offspring at one day of age. The chosen criteria of DEGs is (1) minimum of 1.5-fold difference in normalized read counts between groups; and (2) genes that changed by reads per kilo base per million mapped reads (RPKM) $\geqslant 0.3$ in either control or high-fructose group. As shown in Table 1, we found PPAR signaling pathway is significantly regulated in the liver, heart, and kidney. There were 9, 14, and 19 DEGs related to PPAR signaling pathway identified in the liver, heart, and kidney respectively. Among them, two DEGs, Fabp4 and Cd36, were identified shared by three different organs at postnatal one day. Fabp4 encodes fatty acid-binding protein 4 , is involved in the regulation of glucose and lipid metabolism in relation to inflammatory and metabolic diseases. It has been considered as a biomarker of metabolic and cardiovascular diseases [47]. Cd36 encodes a class B scavenger receptor CD36 in mediating the inflammation, insulin resistance, and oxidative stress involved in hyperlipidemic states. In the kidney, activation of CD 36 and sodium transporter $\mathrm{Na} / \mathrm{K}$-ATPase- $\alpha 1$ could form a pro-inflammatory signaling loop to induce hypertension and kidney disease [48].

Table 1. Significantly regulated peroxisome proliferator-activated receptor (PPAR) pathway in different organs of maternal high-fructose treated offspring at one day of age.

\begin{tabular}{lcllc}
\hline Organ & Count & Gene Symbol & $p$-Value & Benjamini \\
\hline Liver & 9 & $\begin{array}{l}\text { Adipoq, Ehhadh, Fabp3, Fabp4, Pparg, } \\
\text { Cd36, Scd1, Scl27a5 and Sorbs1 }\end{array}$ & $5.1 \times 10^{-2}$ & $4.0 \times 10^{-1}$ \\
\hline Heart & 14 & $\begin{array}{l}\text { Hmgcs2, Acsl1, Angptl4, Aqp7, Cpt1a, } \\
\text { Cpt1b, Ctp2, Dbi, Fabp4, Olr1, Rxrg, } \\
\text { Acaa1, Cd36 and Ubc }\end{array}$ & $1.1 \times 10^{-2}$ & $2.1 \times 10^{-1}$ \\
Kidney & 19 & $\begin{array}{l}\text { Hmgcs2, Acsl3, Adipoq, Angptl4, Cpt1b, } \\
\text { Cyp4a8, Cyp4a1, Fabp1, Fabp4, Fabp7, } \\
\text { Fads2, Lpl, Me1, Ppara, Rxrg, Acaa1, } \\
\text { Cd36, Ubc and Scd }\end{array}$ \\
\hline
\end{tabular}

The DEGs in the PPAR signaling pathway in one-day-old offspring kidney in response to maternal high-fructose intake are illustrated in the Figure 2. Most of DEGs in PPAR signaling pathway in the kidney are different from the other organs, suggesting windows of developmental vulnerability to the same insult may be tissue specific. However, all three PPARs and their downstream signaling are more or less involved in the renal programming. All of these findings suggest that PPARs are involved in maternal high-fructose induced programming in a variety of organs and PPAR pathway might be a universally-therapeutic target for programmed hypertension and metabolic syndrome. 


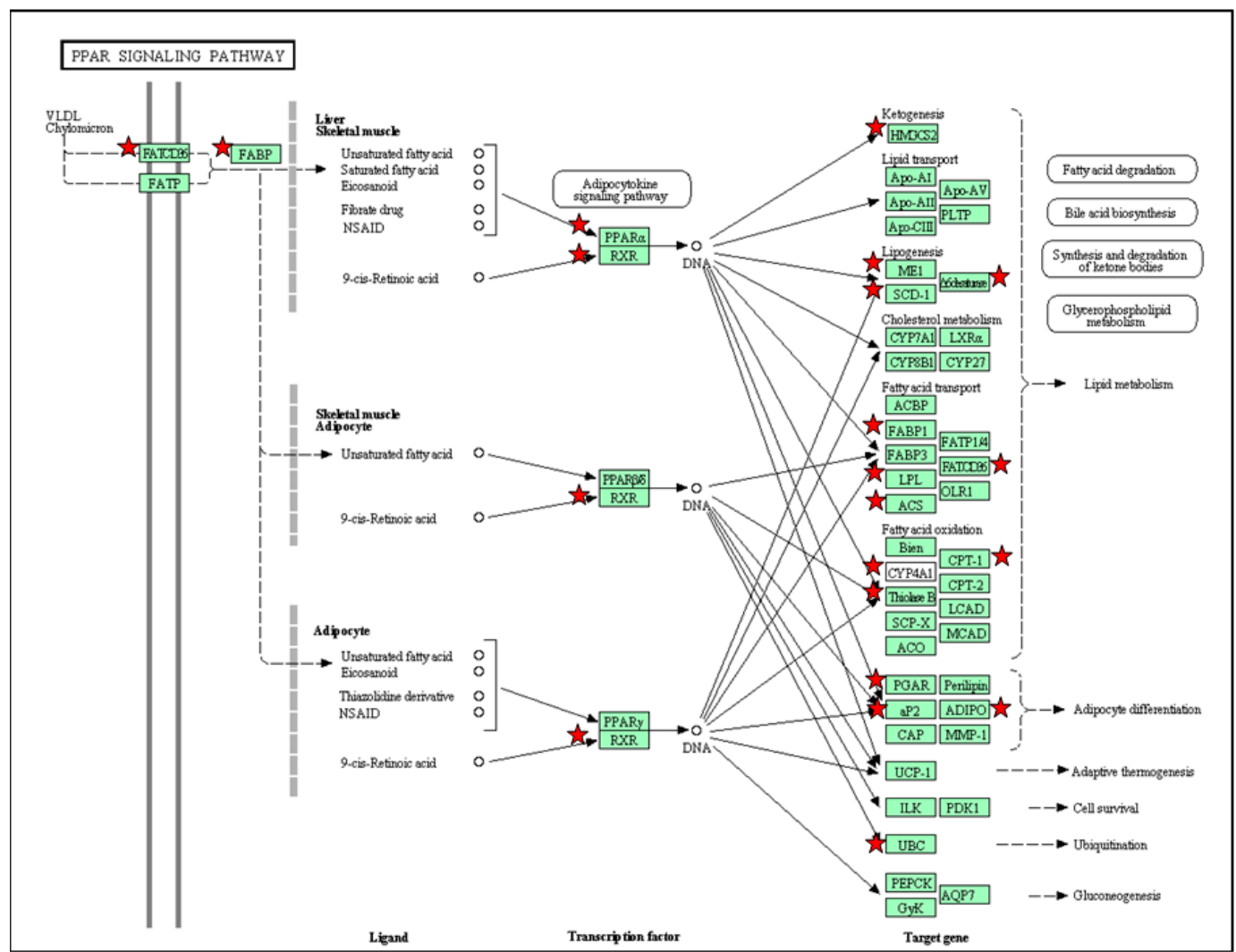

Figure 2. Gene members (green rectangle) in the PPAR signaling pathway that are regulated by maternal high fructose in the male offspring kidney at one day of age (red stars). Data were analyzed using the KEGG pathway feature of the DAVID software [45]. Solid line, downstream signal and PPAR target genes; Dotted line, PPARs regulated mechanisms.

\section{Targeting on PPARs to Prevent Programmed Hypertension and Metabolic Syndrome}

There is a vast body of evidence that has indicated that all three PPARs are involved in the pathogenesis of metabolic syndrome and its comorbidities, and their ligands may have therapeutic potential in treating this cluster of metabolic syndrome [6-8]. To date, however, only a few studies explored the impact of early intervention by PPAR modulators to prevent programmed metabolic syndrome and its related diseases in programming models, especially nutritional programming-induced acquired hypertension. It is quite conceivable that besides hypertension, many other phenotypes of metabolic syndrome could be influenced by such interventions. Thus, for the sake of brevity, we have restricted this review solely to hypertension. We provide an overview of the different animal models used to achieve reprogramming via PPARs in both genetic and acquired animal models of hypertension.

Natural and synthetic agonists of different PPAR isoforms have been studied in genetic or acquired animal models of hypertension [26,49-61]. The overview of studies in Table 2 illustrates that the most commonly used reprogramming targets of PPARs are PPAR $\gamma$ agonists. A subgroup of ARBs can act as a partial agonist of PPAR $\gamma$, which are protective in both genetic and acquired animal models of hypertension. [50,52,59]. Yet their BP-lowering effects may be off-target or $\operatorname{PPAR} \gamma$-independent. On the other hand, selective PPAR $\gamma$ agonists, rosiglitazone and pioglitazone, can be protective in both spontaneously hypertensive rats (SHRs) and developmentally-programmed hypertension [51,56,57]. This may indicate PPAR signaling is a common pathway, whereby both SHRs and acquired programmed hypertension model converge into the same phenotype. However, PPAR $\gamma$ agonists failed to confer antihypertensive effects in the genetic hypertension models of salt-loaded spontaneously-hypertensive stroke-prone rats (SHRSP) [60] and fawn-hooded hypertensive rats 
(FHH) [61]. It is likely that the extent therapeutic outcomes vary depends on the genetics, types of nutritional insults, timing of exposure, and PPAR agonists utilized. Next, little information is available about the reprogramming effect of PPAR $\beta / \delta$ on programmed hypertension [26], especially in nutritional programming-induced acquired hypertension. Moreover, it is of note that some natural PPAR agonists have been examined in developmentally-programmed hypertension $[49,53]$. Given fatty acid derivatives with a wide range of affinity to PPARs, it has been difficult thus far to thoroughly evaluate the specificity of each endogenous ligands to the biology of PPARs [31]. Therefore, there remains a long road ahead to determine how and when to apply reprogramming strategies and decide which isoforms of PPARs are an ideal target in a broad range of programmed hypertension models.

Table 2. Reprogramming aimed at PPARs in developmentally-acquired and genetic hypertension models.

\begin{tabular}{|c|c|c|c|c|}
\hline $\begin{array}{c}\text { Programming Model } \\
\text { [Reference] }\end{array}$ & Strain & PPAR Isoform & Treatment & Reprograming Effects \\
\hline $\begin{array}{l}\text { Prenatal dexamethasone } \\
\text { exposure [49] }\end{array}$ & Wistar & $\operatorname{PPAR} \alpha \operatorname{PPAR} \gamma$ & $\begin{array}{l}\text { Diet high in } \omega-3 \text { fatty acids } \\
\text { from three weeks to six } \\
\text { months of age }\end{array}$ & $\begin{array}{l}\text { Prevented hypertension } \\
\text { and hyperleptinemia at } \\
\text { six months of age }\end{array}$ \\
\hline Low protein diet [50] & Wistar & $\operatorname{PPAR} \gamma$ & $\begin{array}{l}\text { Losartan between two and } \\
\text { four weeks of age }\end{array}$ & $\begin{array}{l}\text { Prevented hypertension } \\
\text { at } 12 \text { weeks of age }\end{array}$ \\
\hline Low protein diet [51] & Wistar & $\operatorname{PPAR} \gamma$ & $\begin{array}{l}\text { Rosiglitazone from three to } \\
\text { six months of age }\end{array}$ & $\begin{array}{l}\text { Prevented hypertension } \\
\text { at six months of age }\end{array}$ \\
\hline $50 \%$ caloric restriction [52] & Sprague-Dawley & $\operatorname{PPAR} \gamma$ & $\begin{array}{l}\text { Losartan between two and } \\
\text { four weeks of age }\end{array}$ & $\begin{array}{c}\text { Prevented hypertension } \\
\text { at } 12 \text { weeks of age }\end{array}$ \\
\hline High fat diet [53] & Sprague-Dawley & $\operatorname{PPAR} \gamma$ & $\begin{array}{c}\text { Conjugated linoleic acid } \\
\text { during pregnancy } \\
\text { and lactation }\end{array}$ & $\begin{array}{c}\text { Failed to confer } \\
\text { antihypertensive effect at } \\
130 \text { days of age }\end{array}$ \\
\hline Genetic hypertension [54] & SHR & $\operatorname{PPAR} \alpha$ & $\begin{array}{l}\text { Clofibrate between nine and } \\
12 \text { weeks of age }\end{array}$ & $\begin{array}{l}\text { Prevented hypertension } \\
\text { at } 12 \text { weeks of age }\end{array}$ \\
\hline $\begin{array}{l}\text { Genetic hypertension plus } \\
\text { high-fat diet [55] }\end{array}$ & SHR & $\operatorname{PPAR} \alpha$ & $\begin{array}{c}\text { Fenofibrate between } 8 \text { and } \\
20 \text { weeks of age }\end{array}$ & $\begin{array}{l}\text { Prevented hypertension } \\
\text { at } 20 \text { weeks of age }\end{array}$ \\
\hline Genetic hypertension [56] & SHR & $\operatorname{PPAR} \alpha \operatorname{PPAR} \gamma$ & $\begin{array}{c}\text { Wy14643 or rosiglitazone } \\
\text { between five and } 13 \text { weeks } \\
\text { of age }\end{array}$ & $\begin{array}{l}\text { Prevented hypertension } \\
\text { at } 13 \text { weeks of age }\end{array}$ \\
\hline Genetic hypertension [26] & SHR & $\operatorname{PPAR} \beta / \delta$ & $\begin{array}{l}\text { GW0742 between } 12 \text { and } 17 \\
\text { weeks of age }\end{array}$ & $\begin{array}{l}\text { Prevented hypertension } \\
\text { at } 17 \text { weeks of age }\end{array}$ \\
\hline Genetic hypertension [57] & SHR & $\operatorname{PPAR} \gamma$ & $\begin{array}{l}\text { Pioglitazone between five } \\
\text { and seven weeks of age }\end{array}$ & $\begin{array}{l}\text { Prevented hypertension } \\
\text { at seven weeks of age }\end{array}$ \\
\hline Genetic hypertension [58] & SHR & $\operatorname{PPAR} \gamma$ & $\begin{array}{l}\text { Magnolol between four and } \\
\text { seven weeks of age }\end{array}$ & $\begin{array}{l}\text { Prevented hypertension } \\
\text { at seven weeks of age }\end{array}$ \\
\hline $\begin{array}{l}\text { Genetic hypertension plus } \\
\text { high-fat diet [59] }\end{array}$ & SHR & $\operatorname{PPAR} \gamma$ & $\begin{array}{l}\text { Telmisartan between eight } \\
\text { and } 17 \text { weeks of age }\end{array}$ & $\begin{array}{c}\text { Prevented hypertension } \\
\text { and renal injury at } 17 \\
\text { weeks of age }\end{array}$ \\
\hline Genetic hypertension [60] & SHRSP & $\operatorname{PPAR} \alpha \operatorname{PPAR} \gamma$ & $\begin{array}{l}\text { Fenofibrate, clofibrate, or } \\
\text { rosiglitazone between five } \\
\text { and } 10 \text { weeks of age }\end{array}$ & $\begin{array}{c}\text { Failed to confer } \\
\text { antihypertensive effect at } \\
14 \text { weeks of age }\end{array}$ \\
\hline Genetic hypertension [61] & $\mathrm{FHH}$ & $\operatorname{PPAR} \gamma$ & $\begin{array}{l}\text { Pioglitazone from two } \\
\text { weeks before birth to four } \\
\text { weeks of age }\end{array}$ & $\begin{array}{c}\text { Failed to confer } \\
\text { antihypertensive effect at } \\
28 \text { weeks of age }\end{array}$ \\
\hline
\end{tabular}

FHH = Fawn-hooded hypertensive rats; SHR $=$ Spontaneous hypertensive rats; SHRSP $=$ salt-loaded spontaneously hypertensive stroke-prone rats.

\section{Conclusions}

Metabolic syndrome in adult life can be programmed by maternal nutritional insults in early life. This concept opens new window to prevent or delay the onset of various phenotypes of metabolic syndrome, like hypertension. The three PPARs, by acting as nutrient sensing signals, are major metabolic regulators and, together, they control BP homeostasis. So far, emerging evidence has indicated that all three PPAR isoforms are involved in the pathogenesis of metabolic syndrome, and their ligands are considered as potential treatments for metabolic syndrome and its related diseases. Studies in short-lived animals, with controlled interventions across their entire lifespan, have provided interesting results on reprogramming strategies to prevent hypertension via targeting on PPARs. However, there remain little data available to decide the "right" PPAR ligand at the "right" time to de-program metabolic syndrome-related hypertension. This is far more challenging in 
human studies. Although the three PPARs share a large overlap of target gene profile, their resultant phenotypes are quite different in a tissue specific manner. Currently available PPAR $\gamma$ agonists and dual agonists presented unwanted and serious side effects [30,62]. Further efforts are required to develop selective PPAR modulators (SPPARMs) with pharmacological efficiency and minimal adverse effects for patients with metabolic syndrome and associated hypertension. Thereby, a greater understanding of the similarity and difference of three PPARs among a variety of programming models with metabolic syndrome and hypertension is essential to developing early intervention to halt the globally growing epidemic of metabolic syndrome-related diseases.

Acknowledgments: This work was supported by the Grant MOST 104-2314-B-182-056-MY3 from Ministry of Science and Technology, Taiwan, and the Grant CMRPG8C0043 and CMRPG8D0202 from Chang Gung Memorial Hospital, Kaohsiung, Taiwan.

Author Contributions: You-Lin Tain: contributed to concept generation, data interpretation, drafting of the manuscript, critical revision of the manuscript and approval of the article; Julie Y. H. Chan: contributed to concept generation, data interpretation, critical revision of the manuscript, and approval of the article; Chien-Ning Hsu: contributed to concept generation, data interpretation, critical revision of the manuscript and approval of the article.

Conflicts of Interest: The authors declare no conflict of interest.

\section{References}

1. Ojeda, N.B.; Grigore, D.; Alexander, B.T. Developmental programming of hypertension: Insight from animal models of nutritional manipulation. Hypertension 2008, 52, 44-50. [CrossRef] [PubMed]

2. Tain, Y.L.; Hsu, C.N.; Chan, J.Y.; Huang, L.T. Renal transcriptome analysis of programmed hypertension induced by maternal nutritional insults. Int. J. Mol. Sci. 2015, 16, 17826-17837. [CrossRef] [PubMed]

3. Rinaudo, P.; Wang, E. Fetal programming and metabolic syndrome. Annu. Rev. Physiol. 2012, 74, 107-130. [CrossRef] [PubMed]

4. McMullen, S.; Langley-Evans, S.C.; Gambling, L.; Lang, C.; Swali, A.; McArdle, H.J. A common cause for a common phenotype: The gatekeeper hypothesis in fetal programming. Med. Hypotheses 2012, 78, 88-94. [CrossRef] [PubMed]

5. Efeyan, A.; Comb, W.C.; Sabatini, D.M. Nutrient-sensing mechanisms and pathways. Nature 2015, 517, 302-310. [CrossRef] [PubMed]

6. Azhar, S. Peroxisome proliferator-activated receptors, metabolic syndrome and cardiovascular disease. Future Cardiol. 2010, 6, 657-691. [CrossRef] [PubMed]

7. Monsalve, F.A.; Pyarasani, R.D.; Delgado-Lopez, F.; Moore-Carrasco, R. Peroxisome proliferator-activated receptor targets for the treatment of metabolic diseases. Mediat. Inflamm. 2013, 2013, 549627. [CrossRef] [PubMed]

8. Ruan, X.; Zheng, F.; Guan, Y. PPARs and the kidney in metabolic syndrome. Am. J. Physiol. Ren. Physiol. 2008, 294, F1032-F1047. [CrossRef] [PubMed]

9. Luo, Z.C.; Xiao, L.; Nuyt, A.M. Mechanisms of developmental programming of the metabolic syndrome and related disorders. World J. Diabetes 2010, 1, 89-98. [CrossRef] [PubMed]

10. Paixão, A.D.; Alexander, B.T. How the kidney is impacted by the perinatal maternal environment to develop hypertension. Biol. Reprod. 2013, 89, 144. [CrossRef] [PubMed]

11. Luyckx, V.A.; Bertram, J.F.; Brenner, B.M.; Fall, C.; Hoy, W.E.; Ozanne, S.E.; Vikse, B.E. Effect of fetal and child health on kidney development and long-term risk of hypertension and kidney disease. Lancet 2013, 382, 273-283. [CrossRef]

12. Tain, Y.L.; Hsieh, C.S.; Lin, I.C.; Chen, C.C.; Sheen, J.M.; Huang, L.T. Effects of maternal L-citrulline supplementation on renal function and blood pressure in offspring exposed to maternal caloric restriction: The impact of nitric oxide pathway. Nitric Oxide 2010, 23, 34-41. [CrossRef] [PubMed]

13. Tain, Y.L.; Lee, W.C.; Hsu, C.N.; Lee, W.C.; Huang, L.T.; Lee, C.T.; Lin, C.Y. Asymmetric dimethylarginine is associated with developmental programming of adult kidney disease and hypertension in offspring of streptozotocin-treated mothers. PLoS ONE 2013, 8, e55420. [CrossRef] [PubMed] 
14. Tain, Y.L.; Leu, S.; Wu, K.L.; Lee, W.C.; Chan, J.Y. Melatonin prevents maternal fructose intake-induced programmed hypertension in the offspring: Roles of nitric oxide and arachidonic acid metabolites. J. Pineal Res. 2014, 57, 80-89. [CrossRef] [PubMed]

15. Tain, Y.L.; Lee, W.C.; Leu, S.; Wu, K.L.; Chan, J.Y. High salt exacerbates programmed hypertension in maternal fructose-fed male offspring. Nutr. Metab. Cardiovasc. Dis. 2015, 25, 1146-1151. [CrossRef] [PubMed]

16. Tain, Y.L.; Sheen, J.M.; Yu, H.R.; Chen, C.C.; Tiao, M.M.; Hsu, C.N.; Lin, Y.J.; Kuo, K.C.; Huang, L.T. Maternal melatonin therapy rescues prenatal dexamethasone and postnatal high-fat diet induced programmed hypertension in male rat offspring. Front. Physiol. 2015, 6, 377. [CrossRef]

17. Tain, Y.L.; Sheen, J.M.; Chen, C.C.; Yu, H.R.; Tiao, M.M.; Kuo, H.C.; Huang, L.T. Maternal citrulline supplementation prevents prenatal dexamethasone-induced programmed hypertension. Free Radic. Res. 2014, 48, 580-586. [CrossRef] [PubMed]

18. Tain, Y.L.; Lee, C.T.; Huang, L.T. Long-term effects of maternal citrulline supplementation on renal transcriptome prevention of nitric oxide depletion-related programmed hypertension: The impact of gene-nutrient interactions. Int. J. Mol. Sci. 2014, 15, 23255-23268. [CrossRef] [PubMed]

19. Tain, Y.L.; Chen, C.C.; Sheen, J.M.; Yu, H.R.; Tiao, M.M.; Kuo, H.C.; Huang, L.T. Melatonin attenuates prenatal dexamethasone-induced blood pressure increase in a rat model. J. Am. Soc. Hypertens. 2014, 8, 216-226. [CrossRef] [PubMed]

20. Wu, T.H.; Kuo, H.C.; Lin, I.C.; Chien, S.J.; Huang, L.T.; Tain, Y.L. Melatonin prevents neonatal dexamethasone induced programmed hypertension: Histone deacetylaseinhibition. J. Steroid Biochem. Mol. Biol. 2014, 144, 253-259. [CrossRef] [PubMed]

21. Meher, A.; Sundrani, D.; Joshi, S. Maternal nutrition influences angiogenesis in the placenta through peroxisome proliferator activated receptors: A novel hypothesis. Mol. Reprod. Dev. 2015, 82, 726-734. [CrossRef] [PubMed]

22. Rees, W.D.; McNeil, C.J.; Maloney, C.A. The roles of PPARs in the fetal origins of metabolic health and disease. PPAR Res. 2008, 2008, 459030. [CrossRef] [PubMed]

23. Zana-Taieb, E.; Pham, H.; Franco-Montoya, M.L.; Jacques, S.; Letourneur, F.; Baud, O.; Jarreau, P.H.; Vaiman, D. Impaired alveolarization and intra-uterine growth restriction in rats: A postnatal genome-wide analysis. J. Pathol. 2015, 235, 420-430. [CrossRef] [PubMed]

24. Diep, Q.N.; Amiri, F.; Touyz, R.M.; Cohn, J.S.; Endemann, D.; Neves, M.F.; Schiffrin, E.L. PPAR $\alpha$ activator effects on Ang II-induced vascular oxidative stress and inflammation. Hypertension 2002, 40, 866-871. [CrossRef] [PubMed]

25. Usuda, D.; Kanda, T. Peroxisome proliferator-activated receptors for hypertension. World J. Cardiol. 2014, 6, 744-754. [CrossRef] [PubMed]

26. Zarzuelo, M.J.; Jiménez, R.; Galindo, P.; Sánchez, M.; Nieto, A.; Romero, M.; Quintela, A.M.; López-Sepúlveda, R.; Gómez-Guzmán, M.; Bailón, E.; et al. Antihypertensive effects of peroxisome proliferator-activated receptor- $\beta$ activation in spontaneously hypertensive rats. Hypertension 2011, 58, 733-743. [CrossRef] [PubMed]

27. Hamblin, M.; Chang, L.; Zhang, J.; Chen, Y.E. The role of peroxisome proliferator-activated receptor $\gamma$ in blood pressure regulation. Curr. Hypertens. Rep. 2009, 11, 239-245. [CrossRef] [PubMed]

28. Duan, S.Z.; Ivashchenko, C.Y.; Whitesall, S.E.; D'Alecy, L.G.; Duquaine, D.C.; Brosius, F.C., III; Gonzalez, F.J.; Vinson, C.; Pierre, M.A.; Milstone, D.S.; et al. Hypotension, lipodystrophy, and insulin resistance in generalized PPAR $\gamma$-deficient mice rescued from embryonic lethality. J. Clin. Investig. 2007, 117, 812-822. [CrossRef] [PubMed]

29. Todorov, V.T.; Desch, M.; Schmitt-Nilson, N.; Todorova, A.; Kurtz, A. Peroxisome proliferator-activated receptor- $\gamma$ is involved in the control of renin gene expression. Hypertension 2007, 50, 939-944. [CrossRef] [PubMed]

30. Choi, S.S.; Park, J.; Choi, J.H. Revisiting PPAR $\gamma$ as a target for the treatment of metabolic disorders. BMB Rep. 2014, 47, 599-608. [CrossRef] [PubMed]

31. Michalik, L.; Auwerx, J.; Berger, J.P.; Chatterjee, V.K.; Glass, C.K.; Gonzalez, F.J.; Grimaldi, P.A.; Kadowaki, T.; Lazar, M.A.; O'Rahilly, S.; et al. International Union of Pharmacology. LXI. Peroxisome proliferator-activated receptors. Pharmacol. Rev. 2006, 58, 726-741. [PubMed]

32. Sugden, M.C.; Caton, P.W.; Holness, M.J. PPAR control: It's SIRTainly as easy as PGC. J. Endocrinol. 2010, 204, 93-104. [CrossRef] [PubMed] 
33. Blanchard, P.G.; Festuccia, W.T.; Houde, V.P.; St-Pierre, P.; Brûlé, S.; Turcotte, V.; Côté, M.; Bellmann, K.; Marette, A.; Deshaies, Y. Major involvement of mTOR in the PPAR $\gamma$-induced stimulation of adipose tissue lipid uptake and fat accretion. J. Lipid Res. 2012, 53, 1117-1125. [CrossRef] [PubMed]

34. Lemay, D.G.; Hwang, D.H. Genome-wide identification of peroxisome proliferator response elements using integrated computational genomics. J. Lipid Res. 2006, 47, 1583-1587. [CrossRef] [PubMed]

35. Rakhshandehroo, M.; Knoch, B.; Müller, M.; Kersten, S. Peroxisome proliferator-activated receptor $\alpha$ target genes. PPAR Res. 2010, 2010, 612089. [CrossRef] [PubMed]

36. Aleshin, S.; Strokin, M.; Sergeeva, M.; Reiser, G. Peroxisome proliferator-activated receptor (PPAR) $\beta / \delta$, a possible nexus of PPAR $\alpha$ - and PPAR $\gamma$-dependent molecular pathways in neurodegenerative diseases: Review and novel hypotheses. Neurochem. Int. 2013, 63, 322-330. [CrossRef] [PubMed]

37. Racasan, S.; Braam, B.; Koomans, H.A.; Joles, J.A. Programming blood pressure in adult SHR by shifting perinatal balance of $\mathrm{NO}$ and reactive oxygen species toward NO: The inverted Barker phenomenon. Am. J. Physiol. Ren. Physiol. 2005, 288, F626-F636. [CrossRef] [PubMed]

38. Tain, Y.L.; Huang, L.T. Restoration of asymmetric dimethylarginine-nitric oxide balance to prevent the development of hypertension. Int. J. Mol. Sci. 2014, 15, 11773-11782. [CrossRef] [PubMed]

39. Polvani, S.; Tarocchi, M.; Galli, A. PPAR $\gamma$ and Oxidative Stress: Con $(\beta)$ Catenating NRF2 and FOXO. PPAR Res. 2012, 2012, 641087. [CrossRef] [PubMed]

40. Zhang, H.; Shao, Z.; Alibin, C.P.; Acosta, C.; Anderson, H.D. Liganded peroxisome proliferator-activated receptors (PPARs) preserve nuclear histone deacetylase 5 levels in endothelin-treated Sprague-Dawley rat cardiac myocytes. PLoS ONE 2014, 9, e115258. [CrossRef] [PubMed]

41. Saad, S.; Agapiou, D.J.; Chen, X.M.; Stevens, V.; Pollock, C.A. The role of Sgk-1 in the upregulation of transport proteins by PPAR- $\gamma$ agonists in human proximal tubule cells. Nephrol. Dial. Transplant. 2009, 24, 1130-1141. [CrossRef] [PubMed]

42. Vallon, V.; Lang, F. New insights into the role of serum- and glucocorticoid-inducible kinase SGK1 in the regulation of renal function and blood pressure. Curr. Opin. Nephrol. Hypertens. 2005, 14, 59-66. [CrossRef] [PubMed]

43. Rizkalla, S.W. Health implications of fructose consumption: A review of recent data. Nutr. Metab. 2010, 7, 82. [CrossRef] [PubMed]

44. Tain, Y.L.; Wu, K.L.; Lee, W.C.; Leu, S.; Chan, J.Y. Maternal fructose-intake-induced renal programming in adult male offspring. J. Nutr. Biochem. 2015, 26, 642-650. [CrossRef] [PubMed]

45. NIH DAVID Bioinformatics Resources 6.7. Available online: http://david.abcc.ncifcrf.gov/ (accessed on 1 December 2015).

46. Koeners, M.P.; Wesseling, S.; Ulu, A.; Sepúlveda, R.L.; Morisseau, C.; Braam, B.; Hammock, B.D.; Joles, J.A. Soluble epoxide hydrolase in the generation and maintenance of high blood pressure in spontaneously hypertensive rats. Am. J. Physiol. Endocrinol. Metab. 2011, 300, E691-E698. [CrossRef] [PubMed]

47. Furuhashi, M.; Saitoh, S.; Shimamoto, K.; Miura, T. Fatty acid-binding protein 4 (FABP4): Pathophysiological insights and potent clinical biomarker of metabolic and cardiovascular diseases. Clin. Med. Insights Cardiol. 2015, 8, 23-33. [CrossRef] [PubMed]

48. Kennedy, D.J.; Chen, Y.; Huang, W.; Viterna, J.; Liu, J.; Westfall, K.; Tian, J.; Bartlett, D.J.; Tang, W.H.; Xie, Z.; Shapiro, J.I.; Silverstein, R.L. CD36 and Na/K-ATPase- $\alpha 1$ form a proinflammatory signaling loop in kidney. Hypertension 2013, 61, 216-224. [CrossRef] [PubMed]

49. Wyrwoll, C.S.; Mark, P.J.; Mori, T.A.; Puddey, I.B.; Waddell, B.J. Prevention of programmed hyperleptinemia and hypertension by postnatal dietary $\omega-3$ fatty acids. Endocrinology 2006, 147, 599-606. [CrossRef] [PubMed]

50. Sherman, R.C.; Langley-Evans, S.C. Antihypertensive treatment in early postnatal life modulates prenatal dietary influences upon blood pressure in the rat. Clin. Sci. 2000, 98, 269-275. [CrossRef] [PubMed]

51. Torres, T.S.; D’Oliveira Silva, G.; Aguila, M.B.; de Carvalho, J.J.; Mandarim-De-Lacerda, C.A. Effects of rosiglitazone (a peroxysome proliferator-activated receptor $\gamma$ agonist) on the blood pressure and aortic structure in metabolically programmed (perinatal low protein) rats. Hypertens. Res. 2008, 31, 965-975. [CrossRef] [PubMed]

52. Hsu, C.N.; Lee, C.T.; Huang, L.T.; Tain, Y.L. Aliskiren in early postnatal life prevents hypertension and reduces asymmetric dimethylarginine in offspring exposed to maternal caloric restriction. J. Renin Angiotensin Aldosterone Syst. 2015, 16, 506-513. [CrossRef] [PubMed] 
53. Gray, C.; Vickers, M.H.; Segovia, S.A.; Zhang, X.D.; Reynolds, C.M. A maternal high fat diet programmes endothelial function and cardiovascular status in adult male offspring independent of body weight, which is reversed by maternal conjugated linoleic acid (CLA) supplementation. PLoS ONE 2015, 10, e0115994. [CrossRef] [PubMed]

54. Yousefipour, Z.; Newaz, M. PPAR $\alpha$ ligand clofibrate ameliorates blood pressure and vascular reactivity in spontaneously hypertensive rats. Acta Pharmacol. Sin. 2014, 35, 476-482. [CrossRef] [PubMed]

55. Chung, H.W.; Lim, J.H.; Kim, M.Y.; Shin, S.J.; Chung, S.; Choi, B.S.; Kim, H.W.; Kim, Y.S.; Park, C.W.; Chang, Y.S. High-fat diet-induced renal cell apoptosis and oxidative stress in spontaneously hypertensive rat are ameliorated by fenofibrate through the PPAR $\alpha$-FoxO3a-PGC-1 $\alpha$ pathway. Nephrol. Dial. Transplant. 2012, 27, 2213-2225. [CrossRef] [PubMed]

56. Wu, L.; Wang, R.; de Champlain, J.; Wilson, T.W. Beneficial and deleterious effects of rosiglitazone on hypertension development in spontaneously hypertensive rats. Am. J. Hypertens. 2004, 17, 749-756. [CrossRef] [PubMed]

57. Dovinová, I.; Barancik, M.; Majzunova, M.; Zorad, S.; Gajdosechová, L.; Gresová, L.; Cacanyiova, S.; Kristek, F.; Balis, P.; Chan, J.Y. Effects of PPAR $\gamma$ agonist pioglitazone on redox-sensitive cellular signaling in young spontaneously hypertensive rats. PPAR Res. 2013, 2013, 541871. [CrossRef] [PubMed]

58. Liang, X.; Xing, W.; He, J.; Fu, F.; Zhang, W.; Su, F.; Liu, F.; Ji, L.; Gao, F.; Su, H.; et al. Magnolol administration in normotensive young spontaneously hypertensive rats postpones the development of hypertension: Role of increased PPAR $\gamma$, reduced TRB3 and resultant alleviative vascular insulin resistance. PLoS ONE 2015, 10, e0120366. [CrossRef] [PubMed]

59. Khan, A.H.; Imig, J.D. Telmisartan provides better renal protection than valsartan in a rat model of metabolic syndrome. Am. J. Hypertens. 2011, 24, 816-821. [CrossRef] [PubMed]

60. Gelosa, P.; Banfi, C.; Gianella, A.; Brioschi, M.; Pignieri, A.; Nobili, E.; Castiglioni, L.; Cimino, M.; Tremoli, E.; Sironi, L. Peroxisome proliferator-activated receptor $\alpha$ agonism prevents renal damage and the oxidative stress and inflammatory processes affecting the brains of stroke-prone rats. J. Pharmacol. Exp. Ther. 2010, 335, 324-331. [CrossRef] [PubMed]

61. Koeners, M.P.; Wesseling, S.; Sánchez, M.; Braam, B.; Joles, J.A. Perinatal Inhibition of NF-kB has long-term antihypertensive and renoprotective effects in fawn-hooded hypertensive rats. Am. J. Hypertens. 2015. [CrossRef]

62. Tenenbaum, A.; Motro, M.; Fisman, E.Z. Dual and pan-peroxisome proliferator-activated receptors (PPAR) co-agonism: The bezafibrate lessons. Cardiovasc. Diabetol. 2005, 4, 14. [CrossRef] [PubMed] 